\title{
COVID-19 and the Role of the State: Evidence from Keren, Eritrea
}

\author{
Biyan Ghebreyesus Okubaghergis \\ Department of History, College of Business and Social Sciences, \\ Adi Keih, Zoba Debub, Eritrea \\ biyangher2@gmail.com
}

\begin{abstract}
The CoviD-19 pandemic has caused the worst socio-economic disruption since World War II. From the integral state perspective, this article explores the Eritrean government's pandemic response and the ramifications for its people. The study seeks to understand the measures taken by the government to contain the virus and their immediate impact on the residents of the city of Keren, using individual stories, in-depth interviews, participant observations, media sources, and archival resources gathered from local and national resource centres in Eritrea between March and July 2020. According to the findings, the state's main measures were restricting large gathering, maintaining complete or partial lockdowns, quarantining persons who might be infected, closing non-essential shops and stores, setting up hotline services, and running massive media campaigns. However, these measures hurt the livelihoods of the majority of residents, leaving many households without any way to earn a living.
\end{abstract}

\section{Keywords}

CoviD-19 - livelihood - locals - Eritrea - Keren

\section{Introduction}

Since late 202O, there has been an unprecedented surge of literature about COVID-19, the virus that began as a localised problem in the People's Republic of China and became a worldwide crisis. Initially, the literature comprised merely descriptive studies about COVID-19, including transmission and prevention, 
diagnosis, treatment, asymptomatic and pre-symptomatic virus shedding, and vaccine development, before moving on to its cascading socio-economic impacts. ${ }^{1}$ The ongoing research effort has now proliferated across a wide range of academic disciplines, such as pharmacy, sociology, economics, military science, anthropology, geography, public health, political science and public policy. An interest in the socio-economic impact of Covid-19 in relation to states' actions in acutely affected countries has been part of this new wave of academic research. ${ }^{2}$

China, being, as far as we know, the place of origin of the Covid-19 pandemic, has been the first site of many scientific investigations about the virus and its immediate impact on various aspects of the local communities. Zhang and Feei Ma discussed the impact of the COVID-19 pandemic on mental health and quality of life among inhabitants of Liaoning Province. ${ }^{3}$ Locals were horrified and apprehensive due to the pandemic and the unprecedented scale of the quarantine and isolation measures taken by the Chinese government. However, as the authors underlined, these findings require an auxiliary and methodical investigation in a larger context.

Even though it is possible to gauge the full socio-economic effect of this global tragedy only after it ends, Chakraborty and Maity explored the formative stage outbreak, trends and effects of CoviD-19 on society and the global environment. They argued that 'COVID-19 is a major public health concern for the world's population and is a leading cause of hospitalisation and death, particularly for middle and old age people in the affected countries'. In a similar vein, the World Health Organisation (wHO) has provided more detailed insight into this conclusion. According to its report, as of November 6 2020,

1 A. Hafeez et al., 'A Review of Covid-19 (Coronavirus Disease-2019) Diagnosis, Treatments and Prevention', EJMO 4:2 (2020), 116-25, https://doi.org/10.14744/ejmo.2020.90853 (accessed 16 June 2020); K. Malden and S. Stephens, 'Cascading Economic Impacts of the Covid-19 Outbreak in China', Economic and Security Review Commission (2020), 1-16.

2 D. S. Hui et al., 'The Continuing 2019-Ncov Epidemic: Threat of Novel Coronaviruses to Global Health - the Latest 2019 Novel Coronavirus Outbreak in Wuhan', International Journal of Infectious Diseases 91 (2020), 264-6; I. Chakraborty and P. Maity, 'CoviD-19 Outbreak: Migration, Effects on Society, Global Environment and Prevention', Journal of Science of the Total Environment 728 (2020), https://doi.org/https://doi.org/10.1016/j.scitotenv.2020.138882 (accessed 20 August 2020).

3 Y. Zhang and Z. Feei Ma, 'Impact of the covid-19 Pandemic on Mental Health and Quality of Life among Local Residents in Liaoning Province, China: A Cross-Sectional Study', International Journal of Environmental Research and Public Health 17:2381 (2020), 1-12, https:// doi.org/doi:10.339o/ijerph17072381 (accessed 10 June 2020).

4 Chakraborty and Maity, 'Covid-19 Outbreak: Migration'. 
COVID-19 has had a death toll of more than 1.2 million people across the globe and affected more than 48 million people in more than 200 countries. $^{5}$

In preliminary studies, the United Nations has revealed that children and women are the main victims of the worldwide spread of the pandemic and the mitigation measures of different states. ${ }^{6}$ While it is deepening pre-existing socio-economic inequalities and exposing women's vulnerabilities in social, political and economic systems, it is having a considerably greater negative impact on children. Children are not direct victims of the contagious disease. They are being affected mainly by the different restriction measures that have been enforced by different countries to stop the spread of the virus, which can be seen in the Eritrean context.

Similarly, Ciotti et al. demonstrated how 'the world has paid a high toll in this pandemic in terms of human lives lost, economic repercussions and increased poverty'. ${ }^{7}$ According to them, even the most developed countries, with their sophisticated healthcare systems, could not adequately shield their people from this pandemic. For example, 'Italy, with its 3.2 hospital beds per 1000 person vs 2.8 in the United States had enormous difficulty to meet the needs of critically ill patients arriving in the hospitals in a short time frame. ${ }^{8}$ As Gramsci and Humphrys remarked, this indicated the decomposition of organic relations. ${ }^{9}$ Despite the increasing common awareness of the harmful impact on people, these states were unable to transcend the limits of a 'state-in itself' to become fortresses for their respective citizens against the virus.

From the political-economic standpoint alone, however, Malden and Stephens, among others, unearthed the economic impact of the Covid-19 outbreak as it unfolded in China and attempted to understand how the subsequent crises have radiated across the global economy and affected the United States. ${ }^{10}$ Immediately after the outbreak of the deadly CoviD-19 in Hubei

5 World Health Organization, 'Coronavirus Disease (Covid-19) Pandemic', 12 April 2020, file://C:/Users/Biyan/Downloads/wou-6-november-cleared.pdf.

6 United Nations, 'Policy Brief: The Impact of CoviD-19 on Women', 18 April 2020, https:// www.un.org/sexualviolenceinconflict/wp-content/uploads/2020/06/report/policy-briefthe-impact-of-covid-19-on-women/policy-brief-the-impact-of-covid-19-on-women-en-1.pdf.

7 M. Ciotti et al.'The Covid-19 Pandemic', Critical Reviews in Clinical Laboratory Science 57:6 (2020), 365-88.

8 Ibid.

9 A. Gramsci, Selections from the Prison Notebooks, ed. and trans. Q. Hoare and S. Nowell (London: Lawrence \& Wishart, 1971), 244; E. Humphrys, 'Anti-Politics, the Early Marx and Gramsci's “Integral State", Thesis Elveven 147:1 (2018), 36-41, https://doi. org/10.1177/o725513618787638 (accessed 1o June 2020); Antonio Gramsci, Il Materialismo Storico e La Filosofia Di Benedetto Croce (Rome: Editori Riuniti, 1977), 48.

Malden and Stephens, 'Cascading Economic Impacts', 12. 
province, the Chinese government enforced quarantines and many restrictions on mobility to check the spread of infection in China. ${ }^{11}$ On 24 January 2020, Wuhan, the capital of Hubei Province, and 12 other cities in the province were locked down, followed by lockdowns of other provinces including Zhejiang, Liaoning and Jiangxi. ${ }^{12}$ These restrictions quickly and radically disrupted production and export flows across the world due to China's position in the global market, cutting deeply into the Unites States' supply chains.

In his article 'The organisation of ideological discourse in times of unexpected crisis: explaining how CoviD-19 is exploited by populist leaders', Prasad observed the impact from another angle. ${ }^{13}$ Having investigated the relevance of the organisation of ideological discourse of Gramsci and Zizek to Indian realities under the influence of CoviD-19, he revealed how Muslims in India became the main victims of the politicisation of COVID-19 by the Hindudominated government of Narendra Modi. ${ }^{14}$ The BJP's leading figures, under the leadership of Modi, have taken the trajectory of the CoviD-19 outbreak as a heuristic tool to promote their Hindutva ideology against the Muslim communities. ${ }^{15}$

In this article I take the case of Eritrea to explore the actions of the state in the light of the situation and its ramification for the people in Eritrea, using Gramsci's view of lo Stato integrale (integral state), a level that corresponds to the needs of the productive forces for development and hence to the interests of the ruling class. ${ }^{16}$ The study, in particular, seeks to understand different protective measures taken by the government of Eritrea to contain the spread of

11 China National Bureau of Statistics, 'National Bureau of Statistics Spokesperson Holds 2020 Press Conference Regarding First Quarter National Economic Growth Performance' [国家统计局新闻发言人就 2020 年一季度国民经济运行情况答记者问],17June 2020, http://www.stats.gov.cn/tjsj/sjjd/202004/t20200417_1739461.html.

D. Welle, 'China Extends Lockdown on Millions in Coronavirus Outbreak', 20 February 2020, https://www.dw.com/en/china-extends-lockdown-on-millions-in-coronavirus-outbreak/ a-52131828.

13 A. Prasad, 'The Organization of Ideological Discourse in Times of Unexpected Crisis: Explaining How CovID-19 is Exploited by Populist Leaders', Leadership (2020), 1-9, https:// doi.org/10.1177/1742715020926783 (accessed 12 July 2020).

14 Gramsci, Selections from the Prison Notebooks; S. Zizek, The Sublime Object of Ideology (New York: Verso, 1989).

15 The Bharatiya Janta Party (BJP or Indian People's Party) is one of the two dominant political parties in the contemporary India. Tracing its heritage back to Synama Prasad Mookerjee's Jana Sangh, the modern-day BJP was established in 1977, resulting from the merger of several other parties. From 2015, it is the India's leading political party in terms of representation in the national-level parliament. The party is strongly linked to far-right Hindu nationalist, Rashtriya Swayamsevak Sangh.

16 Gramsci, Selections from the Prison Notebooks. 
COVID-19 and their immediate impact on the livelihoods of the residents of the city of Keren - particularly farmers, small traders and wage workers. These socio-economic groups were selected because they were overwhelmingly hard hit by severe shortfalls compared to other sections. Findings demonstrated that the state took many measures to curb the spread of CoviD-19, but the most critical were restricting large gathering, maintaining complete or partial lockdowns, quarantining persons who might be infected, closing non-essential shops and stores, setting up hotline services and running a massive media campaign. However, these swift protective measures were not without their problems. They have caused turmoil in the livelihoods of locals.

As noted previously, I have chosen Keren as a case study because it offers insightful lived experiences of local communities for two reasons. First, the Eritrean government's imposition of restrictions on the movement of people to mitigate the spread of the disease in the city has been tougher than any other place in the country. This was probably because of its distinctive geopolitical position, which will be discussed in a later section. Second, because of the amplified containment measures, the residents in Keren were particularly vulnerable to the unintended consequences. This is because of supply chains disruption. Across every sphere, from everyday social activities to the routine business of making a living, the impacts of the lockdown have dramatically worsened the lives of the inhabitants of the city.

The data used in this article were drawn from individual stories, in-depth interviews, participant observations, media sources, and archival resources gathered from local and national resource centres in Eritrea between 27 March and 16 July 2020. In particular, semi-structured interviews and fieldwork notes were two methods for qualitative data collection that informed the findings of the study.

Altogether, 22 people ( 7 women and 15 men) were interviewed, all of whom were permanent residents of Keren. The interviewees included people from all walks of life: ordinary residents, teachers, soldiers, priests and traders. Most of the interviews took between 15 to 40 minutes. All the interviews were conducted by the author in the Tigrinya, Tigre and Bilen languages, which are widely spoken throughout the city and its vicinities. Their stories revealed significant congruencies, which led me to believe that there are shared narratives of the reality on the ground. To avoid any possible harm, all names of interviewees cited in the text have been substituted with the first initials.

This article is also further informed by fieldwork conversation, held around the natural settings of the participants. All the participants (six) were irregular contract workers, who had extensive experience in their respective field of expertise. This method was used to follow up some interesting themes that 
I had observed during the in-depth interviews and participant observations in the fieldwork. However, these conversations were not recorded as some interviewees did not want to be recorded.

The paper first outlines the framework for understanding the state response to Covid-19 by describing the basic tenets of the integral state, before providing the background of the study and highlighting its geographical, demographic, social and economic foundations. It then examines the Eritrean government's actions and their impact on the livelihoods of the residents of Keren, specifically on the locals' livelihood choices. The conclusion reflects on what the Eritrean government's response to CoviD-19 might mean for local people.

\section{Framework for Understanding the State Responding to COVID-19: Lo Stato Integrale}

The research problem, themes of investigation and research questions are grounded in a Gramscian conception of Lo Stato integrale (the integral state). ${ }^{17}$ An important strength of this theoretical framework is that it emphasises the complex web of relationships existing between the state and civil society, and the implications of these relationships on the integral state.

The concept of the integral state takes a central position in Gramsci's Prison Notebooks, which refers to 'a network of social relations for the production of consent, for the integration of the subaltern classes into the expansive project of historical development of the leading social group' ${ }^{18}$ It represents an organic linkage or interplay between political society and civil society, between coercion and consent, or between social hegemony and political government. It also depicts 'a dialectical terrain upon which social classes compete for social and political leadership or hegemony over other social classes.' ${ }^{19}$ In this way, as Gramsci described, the main building blocks of the theory of the integral state are both political society (government, executive, judiciary and army) and civil society (institutions such as churches, schools, trade unions and political parties). ${ }^{20}$

\footnotetext{
17 Gramsci, Selections from the Prison Notebooks, 52.

18 A. Gramsci, Prison Notebooks, vol. 3, ed. and trans. J. A. Buttigieg (New York: Colombia University Press, 2007), 75; (Q6§:88); P. D. Thomas, The Gramscian Moment (Leiden: Brill, 2009), 143 .

19 Ibid., 137.

20 Gramsci, Prison Notebooks, 88; Gramsci, Selections from the Prison Notebooks, 263.
} 
According to Gramsci, concrete forms of the state in the integral state are tailored by the ways in which important classes are framed to win the whole set of relations between rulers and the ruled ${ }^{21}$ This is simply realised through social, political and economic activity. Thus, the state represents both the functions of social hegemony and political government. In other words, the state's role in the integral state encompasses the entire 'complex of practical and theoretical activities with which the ruling class not only justifies and maintains its dominance, but manages to win the active consent of those over whom it rules.' ${ }^{22}$

In this context, as Tok underlined, 'hegemony operates as intellectual-moral activities through the society, in order to impose hegemonic class's conception of the world, and this is the ideological aspect. ${ }^{23}$ However, it should be remembered that while the dominant or ruling class uses its hegemony over its immediate subjects, it plays out its autarchy over those who are non-complacent. The latter option works out if it rests on the consensus of the majority; power functions normally. ${ }^{24}$

In Eritrea, the notions of integral state and hegemony unveil some unique features. In the first place, Gramsci's conception of the 'integral state', which holds political society and civil society to be 'co-extensive' rather than two different entities, has sadly been overlooked within the state apparatus. Since 2000, civil society has had no meaningful space in Eritrea. ${ }^{25}$ The state assigned an omnipotent position to the party and emphasised that it is impossible to carry out the nation-building process without it. The few existing civil society institutions are absorbed into the party structure as auxiliary organisations. Second, even though hegemony still entails the domination of the ruling class as Gramsci asserts, in the context of Eritrea this is not necessarily achieved through consent. Rather, as in many other African states, it mainly depends on 'mechanisms of surveillance and control.' 26

21 Gramsci, Selections from the Prison Notebooks, 182.

22 Ibid., 244 (Q15§10); Humphrys, 'Anti-Politics, the Early Marx and Gramsci's "Integral State", 37 .

23 N. Tok, “'An Essay on Gramsci's Concept of Civil Society", İktisadi ve Idari Bilimler Dergisi 17 (2003), 245.

24 Gramsci, Selections from the Prison Notebooks, 244; C. Buci-Glucksmann, 'Hegemony and Consent: A Political Strategy', in Approaches to Gramsci, ed. A. S. Sassoon (London: Writers and Readers Publishing Cooperative Society, 1982), 124.

25 O. Nur, 'Foreign Policy of Eritrea: Explained in the Light of Democratic Peace Proposition', International Journal of Peace and Development Studies 4:5 (2013), 85, https://doi.org/10.5897/ IJPDS2013.0178 (accessed 12 June 2020).

26 C. Young, The African Colonial State in Comparative Perpective (New Haven, CT, and London: Yale University Press, 1994), 288. 
The ultimate objective of the state is always to creating new and higher types of civilisation, of adapting the civilisation and morality of the broadest popular masses to the necessities of the continuous development of the economic apparatus of production. ${ }^{27}$ Therefore, for Gramsci, a given state is 'ethical in as much as one of its most important functions is to raise the great mass of the population to a particular cultural and moral level, a level (or type) which corresponds to the needs of the productive forces for development, and hence to interests of the ruling class. ${ }^{28}$

This is not, of course, the dominant norm in most despotic states, especially in Africa. The illiberal or unchecked governments attempt to ordain control of political society (i.e., of the state apparatus) over the civil society. ${ }^{29}$ Civil society is not allowed to flourish and stand by itself due to the breakdown of the dialectical unity between political society and civil society, underpinned by instability in the norms of the state or political apparatus. In other words, under such circumstances, both political society and civil society can barely conceive of each other in relation to themselves. The end result is that:

The masses have no other political function than a generic loyalty, of military kind, to a visible or invisible political centre ... mass following is simply for 'manoeuvre' and is kept happy by means of moralising sermons, emotional stimuli, and messianic myths of an awaited golden age, in which all present contradictions and miseries will be automatically resolved and made well. ${ }^{30}$

In this sense, as the context of Eritrea unveils, neither civil society nor the state maintains its autonomy from the ruling party. The party, through its regulatory apparatus, including the bureaucracy, the administration and even the iron fist, embraces the whole society. ${ }^{31}$ The party alone decides the policies of the state, with an emphasis on the principle of social justice. The state considers the party (People's Front for Democracy and Justice or PFDJ) organisation most vital for the exercise of political, social, cultural and economic activities. The party does not represent any particular social class, nor does it reflect a narrow base. Instead it embraces all socio-economic groups that are politically committed.

27 Gramsci, Selections from the Prison Notebooks, 242.

28 Ibid., 258.

29 A. Gramsci, Quaderni Del Carcere, ed. V. Gerratana, 4th ed. (Turin: Einaudi, 1975), 734.

30 Gramsci, Selections from the Prison Notebooks, 15 .

31 Dan Connell, 'Countries at the Crossroads', Freedom House 1997 (2011), 1-13. 
Therefore, in this article, the state's role in responding to the COVID-19 crisis and its implications for the urban people's livelihoods in Keren were examined through this theoretical lens.

\section{Area of Study and CoviD-19}

Keren, also known as Senhit, is the second-largest city in Eritrea and the capital of Anseba region. It is located around 57 miles Northwest of the Eritrean capital, Asmara. It holds many sub-administrative units, including Keren La'elay, Shuq, Geza Woreqet, Geza Banda, Shfshifit, Campo, Keren Jedid, Adi-Habab, Hillet Sudan, Bloko Hashela, Hashela and Waliku.

As of 2019, the city had a total population of around 84, o71 residents and 18, 965 households, with the Blin/Bilen and the Tigre being the two most dominant ethnic groups. The Tigriyna and the Tekuwarir (Arabic speaking) also have a presence, thus making it the most diverse city in Eritrea. ${ }^{32}$ The overwhelming majority of the residents are Sunni Muslims, Catholics or Orthodox Coptics, with very few Protestants. The conventional view is that Keren is a cultural sub-system where the diversity of ethnic groups, religions and languages make it one of the most attractive cities in Eritrea for tourists.

Most of the residents are traditional farmers who grow millets, sorghum and groundnuts. Some people also rely on the irrigational system in the Anseba riverbed, mostly producing oranges, mangoes, guavas, lemons, tomatoes and other fruits. Some households also rely on daily wage labour work, the retail trade and remittances from family members living abroad. The area is also

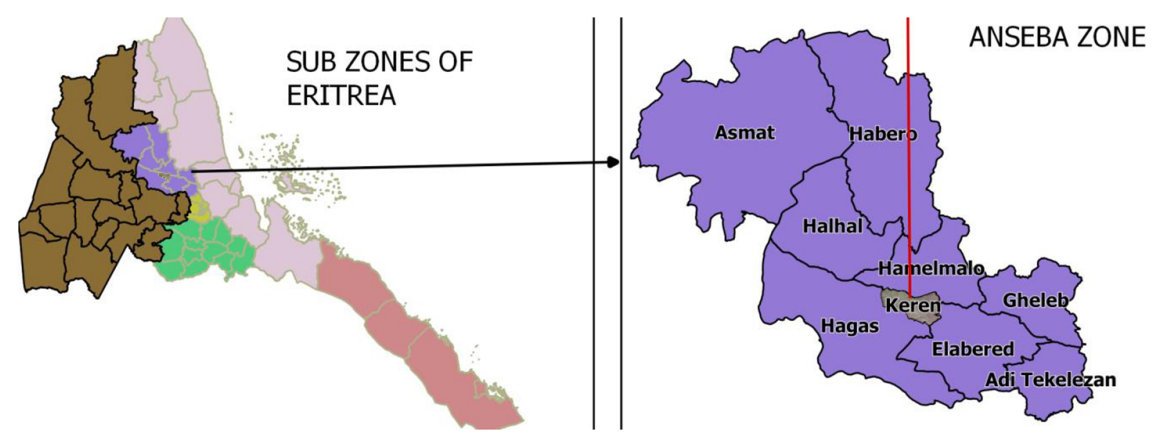

FIGURE 1 Map of Keren sub-zone

$3^{2}$ Zoba Anseba Statistics Office and EMIC Report of 2018. 
known for livestock production. ${ }^{33}$ Historically, Keren households were integrated into commercial circuits connecting to eastern Sudan through the historic smuggling of essential and non-essential goods that began during the onset of Turkish rule in Eritrea. ${ }^{34}$

When it was confirmed on 21 March 2020 that the Covid-19 pandemic had reached Eritrea, there was a lockdown in Keren, part of the nationwide lockdown, for 21 days. That lockdown was subsequently extended further for an unlimited period. ${ }^{35}$ On 27 March 2020, transport lines from Keren to all its neighbouring villages, towns and cities were suspended, preceded by the closure of all essential and non-essential stores. These measures in turn dramatically cut off the flow of people, goods and services from different directions, resulting in a major disruption of supply and demand chains.

However, except for 21 suspected cases, all of whom were discharged when they were confirmed negative after 14 days of mandatory quarantine, as of 7 July 2020, the city had no confirmed positive cases. Keren being a crossroad among Agordet, Afabet and Asmara, the Eritrean government was compelled to impose quarantines and restrictions on the movement of people to avoid the risk of infection.

\section{The Pandemic and the Eritrean Government's Actions}

On 30 January 2020, when the WHO's director declared that CoviD-19 constituted a global health security threat, various countries enforced mandatory confinement rules and regulations to prevent the spread of the disease to new areas or to contain transmission in areas it had already reached. ${ }^{36}$ In the same vein, Eritrea adopted various control measures needed to contain or control the spread of the virus from person to person, regardless of the infection levels in the country. Some local-level actions are discussed below after a brief note on the nationwide practices.

On 25 March, after two series of public guidelines announcements, the National Public Health Emergence Committee (NPHEC) issued additional

33 Informal conversation with the author: EZN, Keren, 2 June 2020.

34 J. Miran, The Red Sea Citizens:Cosmopolitan and Cultural Change in Massawa (Bloomington: Indiana University Press, 2009), 65-9o.

35 R. Bereketeab, 'Covid-19 and Eritrea's Response', Kujenga Amani, 14 May 2020, https:// kujenga-amani.ssrc.org/2020/05/14/covid-19-and-eritreas-response/.

36 Statement by wHo Emergency Committee regarding the outbreak of Coronavirus (covid19) during 2nd meeting of the International Health Regulations (2005) in wHO news room, Geneva, 2020. See https://www.who.int/news/item/29-o6-2020-covidtimeline. 
guidelines that compelled all citizens and foreigners living in the country to take every precaution to prevent the spread of the virus and to strictly follow the government directives for the safety of their lives and the country at large. ${ }^{37}$ However, the majority of citizens saw the state's guidelines as facetious and failed to recognise the seriousness of the information.

After two days of a massive media campaign, on 27 March, the NPHEC declared a nationwide lockdown. ${ }^{38}$ All public and private institutions, restaurants, cafeterias, non-essential shops and stores, and schools were shut down. Furthermore, without prior notification the government froze all public and private bus and taxi services, except for emergency purposes. Consequently, government workers and college students who were away from their homes were stranded. I personally witnessed and experienced excruciating difficulties while waiting for a bus in Asmara on my way to Keren, my home city. Many people were walking in groups of three or four to their homes to escape the unintended consequences of the lockdown. The whole situation reminded me of the late 1980s scenario in Keren, two or three years before the overthrow of Lt. Col. Mengistu Haile Mariam's regime in Eritrea. ${ }^{39}$

All traditional public ceremonies and gathering were also banned. This means that congregations of more than ten individuals for any reason, including sports, cultural events, cinemas and nightclubs, were halted. A task force was assigned to ban the assembly of more than ten people at social events, even those that were of particular importance to almost the entire community. ${ }^{40}$ Churches and mosques were closed, and religious leaders suspended their routine activities on public occasions.

However, neither the NPHEC nor the government seemed ready to face the unintended consequences of these strategies. It appears that they were limited to the short-term view. The post-decree developments left the people and the country on the edge of an abyss. People across the country faced great challenges to live normal lives. Obviously, the respondents saw the incapacity of the government institutions as the main reason for their hardships. However, differences became visible in the way the local people reacted to the state's

37 Eritrea Ministry of Health, 'Ministry of Health: Public Guidelines (No. 3)', Eritrea Profile 27:27, 25 March 2020.

38 Eritrea Ministry of Information, 'Ministry of Health: Public Guidelines (4)', 1 September 2020, http://www.shabait.com/haddas-ertra.

39 Lt.-Col. Mengistu Haile Mariam was a soldier and politician who served as member of Coordinating Committee (1974-7) and Ethiopian president (1977-91). He was also the chair of the Workers' Party of Ethiopia from 1984 to 1991.

40 Eritrea Minstry of Health, 'Ministry of Health: Public Guidelines (No. 3)'. 
preventive measures. For example, a 34-year-old man explained his exasperation with the strategies as follow:

In the first place, our institutions are incapable of dealing with this catastrophe. We have neither healthinfrastructure nor well-equipped medical teams. We know especially how the medical team suffers in dealing with their patients due to a lack of basic medicines and sanitisers. Second, the nature of our government's controls is so bizarre. It fails to give paramount importance to socio-economic repercussions in such a grave situation. The armed forces closed every gate of imports, as if they had enough reserves for the people. As a result, the people in this city are literally left out, susceptible to all kind of problems, from shortages of food to essential commodities. ${ }^{41}$

In sum, the whole story is a Gramsci-type 'organic crisis', which had its roots not in the mode of production, but in the presence of an organic whole. ${ }^{42}$ The government's failure to act swiftly against the negative ramifications of its response to COVID-19, local institutions' inability to deal with the situation and the lack of organisation together represent the existence of a dichotomy and detachment between state and civil society. The state, which is well-known for its national popular mobilisation and aid to its people during dark times, now played an insignificant role in addressing their immediate problems. In turn, this generated a sense of distrust, fear and insecurity among the people.

In Keren, the state's action through its local agents was no different, though extremely complex owing to the city's geopolitical position at the crossroads of the Afabet, Asmara and Agordet roads, and its strong commercial links with eastern Sudan. City controls were tightened by the police, local militia and regular army. To make matters worse, the rules and regulations were constantly changing, unlike in the other parts of the country. The following section discusses respondents' comments on the general outline of the state's localised action in the city.

In accordance with the NPHEC announcement to ensure public safety, the local administration in Keren, through its coviD-19 task force, imposed stringent control measures and curfews to stamp out the virus. The preliminary actions focused on major gathering areas - streets, public places, public transport, schools and non-essential shops.

41 Interview with the author: Mмк, Gezewereqet, Keren, 7 July 2020.

42 Gramsci, Selections from the Prison Notebooks, 244. 
Characteristically, the city's task force also ordered a top-down local mass awareness campaign to encourage locals' proactive and orderly participation in the government's battle against the pandemic. From the very beginning, they established the guidance, 'for the protection of everyone's health, please maintain a distance of at least one meter while queuing. ${ }^{43}$ They published 30,0oo posters and booklets, and distributed them to almost every household in the city to ensure that everyone was aware of all the urgent issues related to the virus. They were heavily involved in public awareness activities using local oral communication tools.

Various teams, including medical experts, local administrators, local administrative staff and soldiers, were deployed to major public gathering hotspots to enforcing mandatory confinement rules. All the eight sub-administrative workers in the city were mobilised to first-level public health emergency response, taking the broadest and most rigorous measures possible. All gates to the city were closed for the unauthorised movement of people. Members of the local militia and the regular army put up checkpoints. The rationale behind the action was to avoid a series of gatherings of locals in markets and other essential distribution points, but it soon became clear that this measure was extended to social or religious gather spaces also. Travel permits that were once used only for monitoring people who were moving towards security zones when the country was under an imminent national security threat now became a mechanism for controlling the movement of people from other cities and villages to Keren and vice versa. ${ }^{44}$

During my fieldwork in Hashela, one of the administrative sub-units of Keren, a 34-year-old man observed:

From March 27, the public transport across the city has been shut down. The city is eerily quiet without transport facilities. There are only a few people on the streets, most of whom are policemen, armed forces and members of city municipalities who were deployed to make sure that the city is empty of people. It looks like a deserted city. Ass businesses have been sealed, confining owners in their home. Living apartments and their surroundings have also been silenced, as the police, army, militia and teams from Ministry of Health workers go door to door. ${ }^{45}$

43 Interview with the author: KME,Keren, 17 June, 2020.

44 Interview with the author: $\mathrm{HHK}$, Keren, 22 June $202 \mathrm{O}$.

45 Interview with the author: АКв, Hashela, Keren 2 July 2020. 
Similarly, both the local and sub-zone authorities, together with security agencies, made joint efforts to prevent Eritreans from sneaking from Sudanese refugee camps. They set up patrol teams to supervise the work, making daily mandatory reports to the concerned authorities in the closest station. A soldier recounted the nature of the control: 'After the declaration of a state of health emergency, the city gates have been ... very rigid. There are checkpoints everywhere, and everybody is subjected to checking now and then. There are no places where smugglers or returnees can easily get a safe haven. The rules are very strict, and people are working hand-in-hand with all institutions.' ${ }^{46}$

The Keren sub-zone also imposed region-wide school closures, affecting more than 25,815 students and 1 ,o14 teachers ( 548 male and 556 female). ${ }^{47}$ The possible losses this could have caused in the learning processes of the younger generation and in the development of human capital are hard to imagine. The regional office of the Ministry of Education in Keren set up a digital library and introduced a local semi-distance learning platform using local-area networks (LAN s). As most interviewees reported, the majority of the students did not get access for two reasons: lack of accessories (laptops, mobiles and tablets) and lack of know-how. A former teacher, now a public servant, explained:

Here, it is hard to adopt any non-traditional classroom for three reasons. First, most of the students and teachers have no experiences of information and communication technology in their schools. This is in addition to a lack of accessories such as laptops, tablets and mobiles. Second, the manner in which the new classroom system (offline learning system) was introduced in the city was uncoordinated and haphazard. The schools often had little control over the acquisition of resources as the management was largely centralised. Third, the office did not set up LAN infrastructure to reach all students. Hashela, Jufa, Bambi and some parts of Adi-Habab, for example, are not covered. ${ }^{48}$

The central focus in all these stories was on multisectorial cooperation, both at high and low levels, to ensure public safety mainly by focusing on self-isolation. The CoviD-19 task force, as a facilitator, established rules and regulations to limit mobility at public gathering spots and check people's compliance. The military and police on the ground themselves become service units in these

\footnotetext{
46 Interviewed by with the author: $\mathrm{WMB}$, Keren, 2 July 2020.

47 Keren Sub Zoba High School administration Statistics Office Report for the academic year 2019/20.

48 Interview with the author: TTs, Shesherema, Keren, 29 June 2020.
} 
stories and their main function was to implement an emergency response, including social distancing, maintaining complete or partial lockdowns, and closing non-essential shops, stores, cafeterias and other services.

At the same time, doctors and nurses worked intensively in hospital and clinics to screen suspected cases and refer them to COVID-19 hospitals or centres. However, there was a clear weakness in Keren's hospital administration when it came to ensuring the facilities and supplies. The majority of interviewees criticised the hospital administration for its lack of preparation to support the rapid emergency responses and poor handling of its own central referral hospital. Ambulances were unreachable. Doctors and nurses were barely equipped to ensure their own safety, let alone the safety of their patients. As one doctor puts it:

From my observation, the administration could have worked more to secure the local community and health workers, but I don't see it on the ground. We don't have anything except a few bottles of alcohol and face masks. If we find one positive patient, as we stand, we are all at risk ... I feel that our lives are in jeopardy. ${ }^{49}$

This refers to the task force's problems in setting priorities. As most interviewees argue, the task force committee mainly prioritised limiting travel, promoting self-isolation and facilitating access to reliable information through their ambulance. It paid less attention to maintaining an adequate supply of essential items and fixing supply chains. As one interviewee put it, the residents and the members of medical teams were critical of the committee for its failure to provide adequate personal protection equipment such as face masks, disinfectant wipes and enough alcohol-based sanitising gels. ${ }^{50}$

Finally, I am going to look at how the mandatory quarantine impacted the locals' livelihoods, which created the perception that the prevention and control strategies, while immediately important, were not well-organised and prepared. It takes the discussion further by comparing the extent of the impact on three socio-economic groups: farmers, retail traders and wage labourers. The local and central state actions had varied impacts on these groups. The degree of variation is directly related to the type of economic activity. As most participants' assessment revealed, the potential benefits were outweighed by the negative consequences of the containment strategy.

49 Interview with the author: MMJ, Keren Hospital, 2 April 2020.

$5^{\circ}$ Interview with the author: zHA, Keren Hotel, 28 June 2020. 


\section{Experiencing Restrictions: Impact on Livelihoods}

Respondents reported that farmers were the first victims of the immediate impact of the Eritrean government actions. Several factors contributed to the heavy losses in this particular socio-economic group. A 67-year-old man described the way they were impacted:

Many of us have gone out of business due to the market collapse because of the lockdowns. We are not able to sell our agricultural products here or outside the city due to the tight controls. In addition to this, the livestock products market was closed by the local authorities. Whenever we go to sell in any way, the armed forces or local municipality authorities catch us. They do not want see crowds gathering across the city. Moreover, even if we find some opportunities to sell, the local people cannot buy because they don't have money ... The state and the local authorities should have set up a new strategy. We are at risk. ${ }^{51}$

As I had spent most of the lockdown in the city and its surrounding, I had opportunities to meet and talk with many farmers. The local authorities' tight controls at checkpoints stalled the flow of imported consumer goods from Tessenei (a town on the Eritrea-Sudan border) to Keren. Most farmers who depended on Sudanese imported goods such as fuel, fertilisers, pesticides and foodstuffs could not get them. These shortages caused significant disruptions in the agricultural and food production chain. An 8o-year-old interviewee said:

We are compelled to depend on few expensive hoarded goods for the very survival of our everyday business. The cost of production has consistently been far greater than the market price of production, and neither the national government nor the local authorities have attempted to address the problem. We are forced to sell our products only in the local market, below normal cost. For example, the price of tomato has not exceeded 5 nakfa per kilo. ${ }^{52}$ This is a fourfold fall in price from what they were before the lockdown. The same story is true with mango, orange and

$51 \quad$ Interview with the author: GOH, Keren, 2 May 2020.

52 nakfa (Tigriyna: Y $^{3} 4$ ) is the name of the current unit of currency in Eritrea, derived from the name of the historic town in the Northern Red Sea Zone, nakfa. Before 1997, both Eritrea and Ethiopia shared a common currency, Ethiopian Birr. This had worked due to their common fiscal and monetary policies. 
vegetable production. In short, all agricultural activities have been negatively affected by the set of rules and regulations. ${ }^{53}$

By contrast, grain prices went up four times, which put a strain not only on farmers but also other socio-economic groups. There was a sudden rush to collect grains from stores. According to interviewees' reports, the cost of wheat flour, millets, corn and sorghum increased from an average of 25 nakfa per $5 \mathrm{~kg}$ before the pandemic to an average of 100 nakfa after the rigorous containment and control measures had been imposed. From the perspective of the locals, there were three main reasons for this market upsurge - the army checkpoints, general supply disruption by the state and hoarding by retail traders, inevitably leading the majority of people to a state of uncertainty. In particular, the state's actions and practices reduced the amount of grains coming from Sudan and Ethiopia. The entry of all essential and non-essential items was considered to be highly risky and a potential danger to the lives of hundreds of thousands of people. Before the new set of restrictions, caravans of goods smugglers and traders had used these lines as a source of livelihoods for the city.

The goal of restriction practices is to ensure health and security, but they have ultimately undermined the small-scale traders' everyday activities. Owners of all shops and stores trading in essential and non-essential goods across the city were forced to close their businesses and stay at home, leading economic activity to halt. This caused economic problems for the overwhelming majority of the families who depended on these activities for their livelihoods. One 64-year-old businessman explained:

This is a tiny city which has been completely sealed off from the rest of the country for almost three months with no supplies. The state ordinance is simply imposed on us without any due attention to the catastrophic implications. Everyone's life comes to a standstill. We cannot even afford loaves of bread in the market, let alone other foodstuffs in shops. People are simply starving. Everything is tragically diminishing. ${ }^{54}$

Within the integral state conception, the state's coercive regulations are just as important as the process of consent (hegemony). Conceiving of the state as something that simply sits above civil society, involved in regulations and coercion alone, however, overlooks the complex of practical and theoretical

53 Interview with the author: GOY, Keren, 19 June 2020.

54 Interview with the author: GMN, Keren, 13 March 2020. 
activities. ${ }^{55}$ In other words, as Texier points out, coercive state rules alone are by no means complete. ${ }^{56}$ The state should be involved in political, social, intellectual and moral activities, with which the dominant class maintains and justifies its authority, to address the socio-economic well-being equations of large sections of the population.

However, there were some people from this socio-economic group who benefited in the midst of the crisis by capitalising on the state's prevention and management strategies. Using an informal market in the city, they reaped enormous profits, far beyond what they had at any other time before the lockdown. According to the interviewees, coffee and sugar prices, for instance, increased from 50-6o nakfa and 10-16 nakfa respectively before the lockdowns to an average of $340-360$ nakfa and $50-70$ nakfa after (Table 1 ).

The majority of the people with whom I lived, worked and talked about this issue felt abandoned by the state and local administration. They criticised them for two reasons: failure to provide at least loaves of bread during the critical time and the lack of legal sanctions against market speculators. These

TABLE 1 Retail price index of consumer goods in Keren before and after the lockdown

\begin{tabular}{|c|c|c|c|}
\hline \multirow[t]{2}{*}{ Foodstuff } & \multirow[t]{2}{*}{ Per unit } & \multicolumn{2}{|c|}{ Price in nakfa } \\
\hline & & Before lockdown & After lockdown \\
\hline Sugar & $1 \mathrm{~kg}$ & $10-16$ & $50-70$ \\
\hline Coffee & $1 \mathrm{~kg}$ & $50-6 o$ & $340-36 o$ \\
\hline Edible oil & $1 \mathrm{~kg}$ & $25-30$ & $100-120$ \\
\hline Spaghetti & $1 \mathrm{~kg}$ & 20 & $40-50$ \\
\hline Pasta (normal) & $1 \mathrm{~kg}$ & 20 & 70 \\
\hline Lentils & $1 \mathrm{~kg}$ & $25-30$ & $70-100$ \\
\hline Wheat flour & $25 \mathrm{~kg}$ & 240 & $1,200-1,300$ \\
\hline Red pepper & $1 \mathrm{~kg}$ & $5^{\circ-6 o}$ & $200-220$ \\
\hline Bread & $1 \mathrm{~kg}$ & $1.5^{\circ}$ & Run out of stock \\
\hline Rice & $1 \mathrm{~kg}$ & $20-30$ & 70 \\
\hline
\end{tabular}

SOURCE: FIELD DATA COLLECTED BY THE AUTHOR IN 2020

55 Gramsci, Selections from the Prison Notebooks, 244.

56 J. Texier, 'Gramsci, Theoretician of the Superstructures', in Gramsci and Marxist Theory, ed. Chantal Mouffe (London: Routledge \& Kegan Paul, 1979), 169. 
criticisms are based on rock hard evidence grounded in robust reality. First, from March to July, for four months, all bakeries were closed due to a shortage of wheat flour. Consequently, many families were unable to feed their children. Second, neither the local authorities nor the state intervened to prevent underground market speculation. This clearly left sufficient scope for the establishment of a market crisis. The illegal traders ran counter to the principles of the state's lockdown measures to promote their self-interest at the expense of the poorer sections of society.

Equally distressing is the impact of state restrictions on daily wage workers. The closure of eateries, restaurants, hotels, bars, social services and construction caused a complete halt to labour demand throughout the city, leading daily wage labourers, who make up a significant portion of the city's workforce, into a socio-economic nightmare. Unemployment in the city reached unacceptable levels. Although the government ordered private and public companies to pay workers until the end of the lockdown, in reality, however, only the public companies did so. ${ }^{57}$ As one private company worker told me, 'most of the private firms have no means and resources to pay their workers for such a long period of time without regular income due to a prolonged economic recession in the country. The government's order is not viable. It was simply devised for public relations consumption'. ${ }^{58} \mathrm{He}$ reflected that the private company's ability to continue to pay former employees, in accordance with the state order, was unrealistic because of the steep fall in their revenues even before the CoviD-19 pandemic.

On 29 May, I had a long informal conversation with six daily wage labourers who had been born and had grown up in my neighbourhood, to get a fuller picture of events on the ground. They were all irregular contract workers. Because I had a long and close acquaintance with them, it was easy for me to talk to them freely for two hours. I asked them about their lives under the CoviD-19 restrictions. They all shared similar stories of despair and hunger caused by the chain of command, from the top down to the district level, but I did not dare to record their conversation to avoid interrupting it. For example, one of them said:

This is the biggest crisis we have ever faced in this city. All businesses are closed, and import and export lines are stopped. The consumption rate has remained sluggish due to unemployment and lack of a safety net

57 Interview with the author: AKB, Keren, 1 April 2020.

$5^{8}$ Interviewed by with the author: GMN, Keren, 22 May 2020. 
or other welfare schemes. Access to public benefits, including the coupons that used to provide goods and services at affordable prices at shops owned by the ruling PFDJ, ${ }^{59}$ are limited or have become inadequate, which has resulted in economic problem for many workers. ${ }^{60}$

Behind each conversation, the fear of worse days ahead was palpable. What struck me most, however, was their overarching sense of being abandoned by the local and national authorities. This was more than a simple expression of lived experiences. What they tended to say is that 'the local and national level authorities have a responsibility to give meaning to the words coming out from the national media, ERITV and Dimitsi Hafash [the only state-owned $\mathrm{TV}$ and radio channels in the country respectively], to take concrete steps and actions' ${ }^{61}$ The locals want the state to be effective and to create the basic conditions needed for them to survive in the current socio-economic problems.

Nonetheless, this sense of outrage was not seen among two groups - public workers and people with secure contracts. This is because the state lived up to its promises to them. It demonstrated its preparedness in addressing their needs. As per the state payment ordinance, all of them received their monthly salaries even without their having to report to work or appear in person on paydays - I myself was among the beneficiaries of this decree. Some ministries went to the extent of serving their workers while they were in their respective towns and cities by sending their finance personnel or wiring the money through different mechanisms such as banks or delegates.

It is significant, however, that many families, churches and community leaders played an important role in helping the needy as part of the state's war against the virus. For example, in the first phase alone, the Catholic Church handed out 800 quintals of various cereals to 640 people from eight different sub-administrations within the city. The justification behind the intervention was clear: 'to ensure that the abandoned people will have something to eat in this critical situation'.62 In the same vein, many affluent families from both the Muslim and the Christian communities took a variety of steps to address

59 People's Front for Democracy and Justice (PFDJ) is the only singular founding and ruling political party of the state of Eritrea, established in 1994 as successor of the extreme leftwing nationalist front, Eritrean People's Liberation Front (EPLF). It has led the country from its independence on 24 May 1991 up to the present. The Chairperson of the party and President of Eritrea, since its inception as a free and independent country, is Isaias Afowerki.

6o Interview with the author: THN, Keren, 29 May 2020.

61 Interviewed with the author: AMH, Keren, 15 June 2020.

62 Interview with the author: AZF, Keren, 29 June 2020. 
the challenges that families in their immediate neighbourhoods faced, such as being unable to buy basic foodstuffs from the retail market.

\section{Conclusion}

Following the outbreak of the CoviD-19 pandemic, many countries imposed effective control measures to stop the virus. The Eritrean government imposed a strict state of emergency to provide sustainable health security in the country. Using a micro-level approach this article has studied the actions of the state in the light of this state of affairs and its ramifications for people in Eritrea. In particular, it has attempted to understand the different measures taken by the government of Eritrea to contain the spread of COVID-19 and its immediate impact on the livelihoods of the residents of Keren.

The findings indicate that the state took many measures to curb the spread of CoviD-19, but the most critical ones were restricting large gatherings, imposing complete or partial lockdowns, quarantining persons who might be infected, closing non-essential shops and stores, setting up hotline services and conducting massive awareness campaigns. In analysing the interviewees' findings, I noticed in particular how the state and local authorities overemphasised the everyday restrictions and checkpoints to stop the spread of the virus. Through its local authorities, the state gave top priority to the battle against the disease in Keren. The local NPHEC brought the whole city to a standstill, showing a command mechanism, but the strategies were not formulated and executed in accordance with the micro-level reality. The police, local militia and regular army on the ground failed to balance the macro-level responsibilities and micro-level realities. Thus, the locals were not impressed at all by the managerialisation of the operation, as it threatened their very survival.

The experiences of Eritreans who live, work and bring up families in Keren show that the state's response to COVID-19 through a set of restrictions and checkpoints affected the smooth running of the socio-economic activities of the majority of inhabitants. It jeopardised the livelihoods of farmers, retail traders and daily wage labourers. It caused them to lose their core bases of livelihood and led to higher-level economic harm. Many of them were left in a state of limbo. They were desperately in need of state intervention to meet their immediate needs. In the technical sense, in Gramsci's language, this is a manifestation of a crisis of political authority. The strategists barely considered the unintended consequences of their actions and the fragility of the Eritrean economy, especially in the planning stage of the lockdown decree. 


\section{Acknowledgement}

I am greatful to Francesca Congiu, Luca Puddu and Elizabeth Stone for their encouragement, editing and constructive comments. I would also like to thank the two anonymous reviewers and editiorial board for their constructive comments and suggestions. 